\title{
Effect of Fiscal and Tax Policy on R\&D Investment: Empirical Evidence from Tax Collection and Management System
}

\author{
Yanyan $\mathrm{Li}^{1 \text {, a }}$ \\ ${ }^{1}$ School of economics, Shandong Women's University, Jinan 250300, China \\ alyynzxy@163.com
}

Keywords: tax preferences, financial subsidies, R\&D investment, incentive effect

\begin{abstract}
With corporate data on tax preferences of additional deductions for $\mathrm{R} \& \mathrm{D}$ spending obtained from tax collection and management system for a city in China from 2008 to 2014, fixed effect model was used to check effect of fiscal and tax policy on R\&D investment of enterprises and difference in effect on enterprises of different sizes. The results indicate: (1) The policy of adding deducted tax preferences plays a limited role in promoting R\&D investment of Large enterprises. However, it is difficult for SMEs to be entitled to benefits from tax preferences due to bad operating conditions. As a result, effect on promoting R\&D investment of SMEs is not significant. (2) Compared with Large enterprises, SMEs obtained a higher proportion of financial subsidies. And financial subsidies play a more significant role in stimulating investment of SMEs. (3) Under the double-incentive policies, $R \& D$ investment of enterprises is less sensitive to financial subsidies. Tax preferences and financial subsidies are mutually complementary in terms of their effect on promoting R\&D investment of enterprises. The results of the study have verified the need to increase the deductions for R\&D of SMEs and prolong the period for $\mathrm{R} \& \mathrm{D}$ companies to cover loss.
\end{abstract}

\section{Introduction}

As a main approach of technological innovation, $R \& D$ investment becomes the main focus for the government to fulfill innovation-driven development. As important means of fiscal policy, tax preferences and financial subsidies are able to play an important role in promoting enterprises to increase $R \& D$ investment. These two policy instruments are irreplaceable theoretically. Thus, they are positioned differently during practical implementation. Tax preferences are able to reduce after-tax costs of $R \& D$ investment of enterprises without the need to screen types of $R \& D$ investment projects of enterprises. They are inclusive to some extent. Financial subsidies provide R\&D companies with capital free of interest and charge in a way that reduces costs of the whole $R \& D$ investment project and helps relieve the financing constraints to which $R \& D$ investment of enterprises is subject. Generally, enterprises will be led to invest capital in R\&D investment projects with higher social benefits, which places a certain limit on R\&D investment projects of enterprises. Thus, the scope covered by benefits from the policy is limited. 
China has adopted two policy instruments, preferential tax preferences and fiscal subsidies, at the same time to promote enterprises to increase R\&D investment. During actual implementation, whether the policy instruments can effectively promote $R \& D$ investment of enterprises is an important issue that needs to be considered in policy formulation and improvement. At present, preferential policies that can directly promote $R \& D$ investment include additional deductions for R\&D investment and accelerated depreciation of fixed assets. The accelerated depreciation policy for R\&D of fixed assets started to be put into force in 2014. Thus, the tax preferences for R\&D investment studied in this paper mainly focus on Additional deductions for R\&D investment. In addition, given the parallel implementation of the two incentive policy instruments, what impact does the double-incentive policy will have on $R \& D$ investment of enterprises? Is the incentive effect of the current policy instruments different to companies of different sizes? Study on the said issues will help provide ideas and references for formulation and improvement of China's fiscal and preferential tax policies for R\&D investment.

\section{Data source and modeling}

\subsection{Data source}

Data come from 4328 enterprises samples entitled to additional deductions during tax declaration when those enterprises made R\&D investment in tax declaration system from 2008 to 2014. After enterprises samples with incomplete data were removed, there were 4320 valid samples. In addition, to reduce deviation from the estimated result due to outlier, all continuous variables were subject to Winsorize processing at the levels of $1 \%$ and $99 \%$. At present, in most studies on effect of tax preference policy, data from listed companies were used for estimation. If data from tax declaration system were selected, the amount of tax preference for additional deductions to which enterprises' R\&D investment was entitled could be obtained directly without estimation. The research results obtained thereby would be more accurate.

\subsection{Modeling}

With reference to the model established by Castellacci and Lie (2015), effect of the policy on additional deductions for R\&D was tested. Wald test and Hausman test were performed respectively to determine the regression model to be used. In accordance with the test results, fixed effect model was selected in the Paper. The specific models are as follows:

$$
\begin{aligned}
& \operatorname{rd}_{\mathrm{it}}=\beta_{0}+\beta_{1} \text { allowance }_{\mathrm{it}-1}+\beta_{2} \mathrm{X}_{\mathrm{it}}+\varepsilon_{\mathrm{t}}+\mathrm{v}_{\mathrm{i}}+\mu_{\mathrm{it}} \\
& \operatorname{rd}_{\mathrm{it}}=\beta_{0}+\beta_{1} \text { subsidy }_{\mathrm{it}}+\beta_{2} \mathrm{X}_{\mathrm{it}}+\varepsilon_{\mathrm{t}}+\mathrm{v}_{\mathrm{i}}+\mu_{\mathrm{it}} \\
& \operatorname{rd}_{\mathrm{it}}=\beta_{0}+\beta_{1} \text { subsidy }_{\mathrm{it}}+\beta_{2} \text { allowance }_{\mathrm{it}-1}+\beta_{3} \mathrm{X}_{\mathrm{it}}+\varepsilon_{\mathrm{t}}+\mathrm{v}_{\mathrm{i}}+\mu_{\mathrm{it}}
\end{aligned}
$$

In model (1), effect of tax preferences on enterprises’ R\&D investment was verified. To prevent from being endogenous, level of tax preference delayed for one period was used as explanatory variable $^{(1)}$. In model (2), effect of income from governmental subsidies on enterprises' R\&D investment was verified. Subscripts $i$ and $t$ respectively means different enterprise sample and different time, $\varepsilon_{\mathrm{t}}$ means fixed time effect, $\mathrm{v}_{\mathrm{it}}$ means fixed individual effect, and $\mathrm{u}_{\mathrm{it}}$ means random error term. In model (3), effect on enterprises' R\&D investment under double incentives, tax preference and financial subsidies, was verified.

\footnotetext{
(1) There will be 2650 valid data after the tax preference has been delayed for one period
} 


\subsubsection{Explained variable}

Enterprises’ R\&D investment intensity is measured with R\&D investment divided by operating income (excluding tax-free income).

\subsubsection{Explanatory variable}

Main explanatory variables are financial subsidies and tax preferences. Financial subsidies are measured with the proportion which tax-free income from governmental subsidies obtained by enterprises accounts for in operating income of enterprises. Level of tax preference to which enterprises are entitled due to additional deductions policy is measured with declared $R \& D$ expenses multiplied by $50 \%$ and by applicable tax rate. However, since enterprises may be entitled to preferential tax rate, level of tax preference calculated by the said method will be lower for the enterprises where preferential tax rate is applicable if enterprises' $R \& D$ expenses are same. Thus, to prevent interference from difference in tax rate on the variable preference level and prevent from being endogenous, tax preference is measured with $R \& D$ spending declared by enterprises multiplied by $50 \%$ divided by earnings before interest and tax with one period delayed.

\subsubsection{Control variables}

Table 1 Definition of Variables

\begin{tabular}{|c|c|c|}
\hline Name & Symbol & Definition \\
\hline R\&D intensity & $\mathrm{rd}_{\mathrm{it}}$ & R\&D expenditure/operating income \\
\hline Financial subsidies & subsidy $_{\text {it }}$ & Income from subsidies/operating income \\
\hline Tax preference & allowance $_{i t-1}$ & $\begin{array}{l}\text { Delay R\&D expenditure*50\%/earnings before } \\
\text { interest and tax for one period }\end{array}$ \\
\hline Size of enterprise & size $_{\text {it }}$ & Take the logarithm of total assets \\
\hline Profit margin & profit $_{\mathrm{it}-1}{ }^{(1)}$ & $\begin{array}{c}\text { Delay total profit/operating income for one } \\
\text { period }\end{array}$ \\
\hline Asset-liability ratio & debt & Total liabilities/total assets \\
\hline Interest rate & interest $_{\text {it }}$ & Financial expenses/total liabilities \\
\hline Management expenses & expense $_{\text {it }}$ & Take the logarithm of management expenses \\
\hline High technology & tech $_{\text {it }}$ & $\begin{array}{c}1 \text { for high-tech enterprises } \\
0 \text { for non-high-tech enterprises }\end{array}$ \\
\hline Industry & industry & Numerical variable $(1-9)^{2}$ \\
\hline Year & year & Control \\
\hline
\end{tabular}

In order to control other factors that may affect the R\&D investment of enterprises, with reference to Huang Xin, Chen Xinyuan (2011), Xie Weimin and Fang Hongxing (2011), Zhu Yan and Zhang Mengchang (2013) et al, size of enterprises, gross profit margin, debt ratio, management costs, interest rate and other items are selected as control variables. Generally, due to enterprises' advantage in economies of scale, the larger the scale is, the more the profits which enterprises obtain from economies of scale will be. Thus, enterprises will have a smaller demand for R\&D investment and more tend to reduce R\&D investment. High profit margin means good performance in current operating items of enterprises. Hence, enterprises will be less concerned about future business performance. They will give less consideration to the long-term investment, such as R\&D event. As a result, the higher the profit margin is, the lower the enterprises' R\&D investment

\footnotetext{
${ }^{\mathbb{1}}$ To prevent being endogenous, interest rate is delayed for one period since expense-based R\&D investment is not deducted from total profit.
} 
intensity may be. However, if profit margin of enterprises is higher due to the motivation of tax avoidance or the virtuous circle of $R \& D$ and profit, the amount of $R \& D$ investment may be higher. On the basis of risk aversion and preference, the higher the debt ratio is, the greater the financial risk which enterprises face will be. Thus, enterprise will be more inclined to reduce $R \& D$ investment. In accordance with organization theory, as organizational slack, management expenses of enterprises are able to provide capital buffer for enterprises' R\&D investment, improve management's confidence in the amount of capital holdings and influence enterprises' decision on R\&D investment. The higher the enterprises' management expenses are, the higher the enterprises' $\mathrm{R} \& \mathrm{D}$ investment intensity will be. The interest rate indicates the financing cost of enterprises. When the financing cost is high, the enterprises' R\&D investment will be affected. In addition, whether the enterprise is high-tech and the industry to which it is subordinate may also have impacts on the R\&D investment. Table 1 shows definition of variables.

\section{Empirical analysis}

\subsection{Descriptive statistical analysis}

Table 2 shows the descriptive statistics of the main variables. According to Table 3, the average R\&D investment intensity of sample enterprises is $4.52 \%$, which indicates high R\&D input of sample enterprises. However, there is a large difference in $R \& D$ input. The maximum is 1.087 . Namely, R\&D investment over the current period is 1.087 times of operating income over the current period. The minimum is $0.028 \%$ only. The average intensity of financial subsidies obtained by enterprises is $2.51 \%$, the maximum is $71.6 \%$, and the minimum is 0 . There is a large difference in financial subsidies obtained by enterprises. There is a much larger difference in intensity of tax preference obtained by enterprises. The average is $11.4 \%$, the maximum is 2.564 , and the minimum is negative, which means losses in sample enterprises in accordance with calculation method for intensity of tax preference. It is difficult for enterprises subject to loss to be entitled to tax preference, however.

Table 2 Statistical Description of Main Variables

\begin{tabular}{|c|c|c|c|c|c|}
\hline Variable & $\begin{array}{c}\text { Number of } \\
\text { samples }\end{array}$ & Mean & SD & Mini. & Maxi. \\
\hline R\&D intensity & 4320 & 0.0452 & 0.158 & 0.000281 & 1.087 \\
\hline Financial subsidies & 4320 & 0.0251 & 0.106 & 0 & 0.716 \\
\hline Tax preference & 4320 & 0.114 & 0.410 & -1.457 & 2.564 \\
\hline Size of enterprise & 4320 & 18.70 & 1.632 & 14.76 & 22.65 \\
\hline Profit margin & 4320 & 0.0145 & 0.434 & $-3.383^{(1)}$ & 0.492 \\
\hline Asset-liability ratio & 4320 & 0.483 & 0.230 & 0.0247 & 0.999 \\
\hline Interest rate & 4320 & 0.0112 & 0.0345 & $-0.171^{(2)}$ & 0.108 \\
\hline Management expenses & 4320 & 16.26 & 1.212 & 13.27 & 19.33 \\
\hline High technology & 4320 & 0.767 & 0.423 & 0 & 1 \\
\hline
\end{tabular}

\subsection{Test for difference in average of tax preference and of financial subsidies}

To test policy intensity of tax preference and financial subsidies for enterprises of different sizes,

\footnotetext{
(1) When accounting profit is negative, the calculated gross profit margin is negative

(2) When interest income over the current period is higher than interest expense and service charge, financial expense is negative and then the calculated interest rate is negative.
} 
with Regulations on Classification Criteria of SMEs as criteria, samples enterprises were divided into SMEs and Large enterprises in accordance with total assets, operating income and number of employees of enterprises. T test was conducted for difference in average intensity of tax preference and financial subsidies in different sizes. Table 3 shows the results. The test results show the average proportion of financial subsidies in operating income is 0.029 for SMEs and 0.005 for Large enterprises. The average proportion of additional deductions from tax preference in earnings before interest and tax is 0.12 for SMEs and 0.083 for Large enterprises. Intensity of financial subsidies of SMEs, of which significance level is 5\%, is higher than that of Large enterprises. The test results indicate more financial subsidies and tax preferences flow into SMEs.

Table 3 Difference in Average Intensity of Tax Preference and Financial Subsidies in Different Sizes

\begin{tabular}{|c|c|c|c|}
\hline & SMEs & Large enterprises & T value \\
\hline Number of samples & 3663 & 657 & \\
\hline $\begin{array}{c}\text { Intensity of financial } \\
\text { subsidies }\end{array}$ & 0.029 & 0.005 & $-5.2206^{*}$ \\
\hline Intensity of tax preference & 0.120 & 0.083 & $-2.1100^{*}$ \\
\hline
\end{tabular}

\subsection{Analysis of effect regression of tax preference and financial subsidies}

Table 4 shows the results after models (1) and (2) were used to respectively inspect incentive effect of tax preference and financial subsidies on R\&D investment. As shown in Table 5, preferential tax policy based on additional deduction plays an insignificant incentive role in enterprises' R\&D investment on the whole. In further analysis, inspection results based on size of enterprises show additional deduction policy is able to promote Large enterprises to increase $R \& D$ investment but plays an insignificant role in promoting R\&D investment of SMEs, which is consistent with the relation demonstrated by Feng Haihong et al (2015) between size of enterprises and preferential tax policy. The reason may be that a large number of SMEs entitled to additional deductions and tax subsidies make low profit and some are subject to losses. In case of losses, it is still difficult for enterprises entitled to tax preference based on additional deductions to benefit from such preference practically. Thus, incentive effect of tax preference is limited on R\&D investment of SMEs. Financial subsidies are able to play a significant role in promoting enterprises to increase R\&D investment. Besides, their incentive effect on R\&D investment of SMEs is much higher than that on Large enterprises. However, incentive effect of financial subsidies on R\&D investment of SMEs is based on high rate of financial subsidies. As mentioned above, the average rate of financial subsidies for SMEs is $2.86 \%$, which is much higher than that for Large enterprises, $0.53 \%$. And financial subsidies available to SMEs samples may reach $71.6 \%$ of operating income as a maximum. Thus, from the perspective of level of financial subsidies, their effect on promoting enterprises' $R \& D$ investment is likely to be inefficient.

In terms of control variables, both profit margin and organizational slack have significant positive effects on $R \& D$ investment while interest rate and size of enterprises have significant negative effects. What needs to be specifically mentioned is no evident correlation between whether the enterprise is high-tech and intensity of enterprises' $R \& D$ investment. The main reason is that preferential tax rate for high-tech enterprises is designed for industry support, instead of enterprises' R\&D investment. Even in case of high intensity of high-tech enterprises' R\&D investment, impact of preferential tax rate on $\mathrm{R} \& \mathrm{D}$ investment is indirect. The inspection results are consistent with the widespread idea that effect of tax preference based on tax rate on R\&D investment and technology innovation is limited (Xue Wei et al., 2014; Ren Haiyun, Song Weichen, 2017). 
Table 4 Results of Inspection for Effect of Single Financial or Tax Incentive Policy

\begin{tabular}{|c|c|c|c|c|c|c|}
\hline \multirow{2}{*}{ Variable } & \multicolumn{3}{|c|}{ Model (1) } & \multicolumn{3}{c|}{ Model (2) } \\
\cline { 2 - 7 } & samples & SMEs & $\begin{array}{c}\text { Large } \\
\text { enterprises }\end{array}$ & Full samples & SMEs & $\begin{array}{c}\text { Large } \\
\text { enterprises }\end{array}$ \\
\hline allowance & 0.0003 & 0.0020 & $0.0092^{* * *}$ & & & \\
\hline & $(0.12)$ & $(0.53)$ & $(9.02)$ & & & \\
\hline subsidy & & & & $0.377^{* * *}$ & $0.401^{* * *}$ & $0.163^{* * *}$ \\
\hline & & & & $(15.89)$ & $(14.75)$ & $(5.66)$ \\
\hline profit & $0.0277^{* * *}$ & $0.0290^{* * *}$ & -0.0007 & $0.0368^{* * *}$ & $0.0384^{* * *}$ & 0.0016 \\
\hline & $(6.66)$ & $(6.10)$ & $(-0.22)$ & $(9.44)$ & $(8.69)$ & $(0.46)$ \\
\hline size & $-0.0143^{* *}$ & $-0.0168^{* *}$ & -0.0009 & $-0.0144^{* *}$ & $-0.0163^{* *}$ & -0.0013 \\
\hline & $(-2.89)$ & $(-2.75)$ & $(-0.50)$ & $(-3.14)$ & $(-2.91)$ & $(-0.70)$ \\
\hline debt & -0.0013 & -0.0028 & -0.0029 & -0.0008 & -0.0054 & 0.0023 \\
\hline & $(-0.11)$ & $(-0.20)$ & $(-0.77)$ & $(-0.07)$ & $(-0.42)$ & $(0.54)$ \\
\hline interest & $-0.255^{* * *}$ & $-0.314^{* * *}$ & 0.0095 & $-0.271^{* * *}$ & $-0.328^{* * *}$ & 0.0114 \\
\hline & $(-5.58)$ & $(-5.56)$ & $(0.66)$ & $(-6.41)$ & $(-6.32)$ & $(0.73)$ \\
\hline expense & $0.0146^{* * *}$ & $0.0184^{* * *}$ & 0.0006 & $0.0145^{* * *}$ & $0.0192^{* * *}$ & 0.0007 \\
\hline & $(3.47)$ & $(3.35)$ & $(0.47)$ & $(3.73)$ & $(3.80)$ & $(0.56)$ \\
\hline tech & 0.0042 & 0.0053 & 0.0002 & 0.0059 & 0.0060 & 0.0008 \\
\hline & $(1.01)$ & $(1.02)$ & $(0.19)$ & $(1.55)$ & $(1.25)$ & $(0.66)$ \\
\hline Year & Control & Control & Control & Control & Control & Control \\
\hline Industry & Control & Control & Control & Control & Control & Control \\
\hline Constant & 0.0683 & 0.0591 & 0.0189 & 0.0619 & 0.0283 & 0.0223 \\
\hline & $(0.76)$ & $(0.54)$ & $(0.53)$ & $(0.74)$ & $(0.28)$ & $(0.58)$ \\
\hline $\mathrm{R}^{2}$ (within) & 0.060 & 0.070 & 0.271 & 0.193 & 0.211 & 0.150 \\
\hline $\mathrm{F}$ & 8.875 & 8.249 & 8.975 & 33.300 & 29.467 & 4.266 \\
\hline$N$ & 2650 & 2192 & 458 & 2650 & 2192 & 458 \\
\hline
\end{tabular}

Note: The part in brackets is t statistics; *, ** and ${ }^{* * *}$ respectively mean being significant at the level $5 \%, 1 \%$ and $0.1 \%$

Table 5 Results of Inspection for Effect of Double-Incentive Policies

\begin{tabular}{|c|c|c|c|}
\hline \multirow{2}{*}{ Variable } & \multicolumn{3}{|c|}{ Model (3) } \\
\cline { 2 - 4 } & Full samples & SMEs & Large enterprises \\
\hline allowance $_{\text {it- } 1}$ & $0.0006(0.23)$ & $0.0010(0.33)$ & $0.0082^{* * *}(8.26)$ \\
\hline subsidy $_{\text {it }}$ & $0.260^{* * *}(11.85)$ & $0.271^{* * *}(10.70)$ & $0.128^{* * *}(4.97)$ \\
\hline size & $-0.0025(-0.59)$ & $-0.0035(-0.67)$ & $-0.0013(-0.80)$ \\
\hline profit & $-0.0919^{* * *}(-19.68)$ & $-0.0937^{* * *}(-17.81)$ & $0.0082(1.72)$ \\
\hline debt & $-0.0272^{*}(-2.54)$ & $-0.0323^{*}(-2.51)$ & $-0.00346(-0.83)$ \\
\hline interest & $-0.282^{* * *}(-7.03)$ & $-0.351^{* * *}(-7.10)$ & $-0.0001(-0.00)$ \\
\hline expense & $0.0136^{* *}(3.80)$ & $0.0192^{* * *}(4.13)$ & $0.0006(0.56)$ \\
\hline current & $-0.0009(-1.70)$ & $-0.0010(-1.65)$ & $-0.0006^{*}(-2.08)$ \\
\hline tech & $0.0037(1.06)$ & $0.0045(1.03)$ & $0.0006(0.58)$ \\
\hline Industry & Control & Control & Control \\
\hline Year & Control & Control & Control \\
\hline R-sq(within $)$ & 55.01 & 47.10 & 0.3509 \\
\hline F value & 0.3182 & 0.5558 & 10.98 \\
\hline Prob $>$ F & 0.0000 & 0.0000 & 0.0000 \\
\hline $\mathrm{N}$ & 2650 & 2192 & 458 \\
\hline
\end{tabular}

Note: The part in brackets is t statistics; *, ** and *** respectively mean being significant at the level $5 \%$, $1 \%$ and $0.1 \%$ 
Model (3) was used to inspect double incentive effect on R\&D investment of full samples, SMEs and Large enterprises. Table 5 shows the detailed results. Inspection results based on model (3) are basically consistent with those based on models (1) and (2). Preferential tax policies play a significant but limited role in promoting Large enterprises' $\& \& D$ investment and an insignificant role in small-sized enterprises' $R \& D$ investment. Financial subsidies play a greater role in promoting R\&D investment of SMEs than in that of Large enterprises. However, under action of double-incentive policy, incentive effect of financial subsidies is less on R\&D investment of SMEs, which indicates implementation of preferential tax policy makes R\&D enterprises less sensitive to financial subsidies. On the whole, incentive effect of preferential tax policy and financial subsidies is mutually complementary on enterprises’ R\&D investment.

\section{Conclusions and policy suggestions}

The influence effect of financial subsidies and tax preferences on $R \& D$ investment is systematically analyzed with the tax declaration data with additional deductions of tax preferences for R\&D investment obtained through R\&D investment in a city during 2008-2014 for enterprises in the paper, and the result indicates that: (1) small and medium sized enterprises obtain more tax preference subsidies and financial subsidies of $R \& D$ investment than large enterprises, but the facilitation function for tax preference to SMEs is limited. (2) The financial subsidies can increase the cash flow for enterprises more directly than tax preferences, so the incentive function of financial subsidies for small and medium sized enterprises with financing difficulty to the R\&D investment is greater than that for large enterprises. The following three suggestions are proposed to optimize tax incentive policy for Chinese R\&D investment based on the research conclusions:

Firstly, the implementation of tax preference policy for enterprises with loss is fully considered. It is specified in China currently that there is loss remedy period of five years, and it is specified in the latest No. 119 Tax (2015) Notice that there is a traceability period of three years at most if the $R \& D$ investment of tax preference is not enjoyed. If the enterprise loss is not remedied within five years, it is adverse for dispersion and defusion for R\&D investment risk. So it is suggested that the loss remedy period should be lengthened for additional deduction of $\mathrm{R} \& \mathrm{D}$ which cannot be actually enjoyed or tax return should be conducted for the insufficient deduction part in form of cash after loss remedy period and the traceability period.

Secondly, the tax preference strength can be increased and tax incentive ways can be reformed. The incentive ways for tax policy to $R \& D$ investment of enterprises are mainly additional deduction and tax credit in terms of experience of various countries. The preference strength for the way of additional deduction will be affected by enterprise profit status and applicable tax rate, and the preference strength enjoyed by small and micro enterprises and hi-tech enterprises with treatment of low tax rate is lower on the contrary for the same R\&D investment amount, thus it is deviated from the policy target. Certain ratio of $R \& D$ investment for enterprises is deducted from the taxable amount payable for tax credit, directly lowering the enterprise burden of income tax, so its preference degree is higher than that of policy for additional deduction. The additional deduction should be changed into direct tax credit in proper time, if tax incentive is conducted and tax preference strength is increased pertinent to R\&D investment.

Thirdly, the financial support strength for R\&D investment of small and medium sized enterprises should be increased. Small and medium sized enterprises are the subjects of technological innovation, but there are few measures specially pertinent to innovation of small and medium sized enterprises among tax incentive policies for Chinese R\&D investment currently. It was proposed that the ratio of additional deduction was increased to $75 \%$ pertinent to small and medium sized technology-based enterprises in China in 2017, thus increasing the tax preference 
strength for R\&D investment of small and medium sized enterprises, and filling the blank that the policy for additional deduction is the special preferential policy to R\&D investment for small and medium sized enterprises. The government can subsidize R\&D investment for small and medium sized enterprises in ways such as innovation voucher, etc, so as to increase the financial subsidy efficiency for direct financial subsidy provided for enterprises. Financing for small and medium sized enterprises can also be achieved through indirect ways such as strengthening venture fund, etc, pertinent to the financing dilemma for $R \& D$ investment of small and medium sized enterprises, besides providing financial subsidies.

\section{References}

[1] Boris Lokshin, Pierre Mohnen. How effective are level-based R\&D tax credits? Evidence from the Netherlands [J]. Applied Economics, 2010,040(12):1527-1538.

[2] Mulkay B, Mairesse J. The R\&D tax credit in France: assessment and ex ante evaluation of the 2008 reform [J]. Nber Working Papers, 2013, 65(3):746-766.

[3] Baghana R, Mohnen P. Effectiveness of R\&D Tax preferences in Small and Large Enterprises in Quebec [J]. Small Business Economics, 2009, 33(1):91-107.

[4] Castellacci F, Lie C M. Do the effects of R\&D tax credits vary across industries? A meta-regression analysis [J]. General Information, 2015, 44(4):819-832.

[5] Kuang Xiaoping, Xiao Jianhua. Integration of Preferential Tax Policies for Development of China's Independent Innovation Ability: Analysis of Tax Preference for High-tech Enterprises[J]. Contemporary Finance \& Economics, 2008, 01:23-27.

[6] Zhou Keqing, Jing Jiao. Test for Incentive Effect of Tax Preferential Policies on R\&D: Taking the Companies Listed on GEM as an Example [J]. Taxation Research, 2012, 06:20-24.

[7] Hu Huaxia, Hong Hong, Xiao Lulu, Liu Wen. Tax Preference and R\&D Investment: The Mediating Role of Property Nature Adjustment and Cost Stickiness[J]. Scientific Research Management, 2017, 38(06): 135-143.

[8] Oliviero A. Carboni. $R \& D$ subsidies and private $R \& D$ expenditures: evidence from Italian manufacturing data [J]. International Review of Applied Economics, 2011, 25(4):419-439.

[9] Busom I, Corchuelo B, Martínez-Ros E. Tax preferences... or subsidies for business R\&D?[J]. Small Business Economics, 2014, 43(3):571-596.

[10] Romero-Jordán D, Delgado-Rodríguez M J, Álvarez-Ayuso I, et al. Assessment of the public tools used to promote R\&D investment in Spanish SMEs[J]. Small Business Economics, 2014, 43(4):959-976.

[11] Xie Weimin, Fang Hongxing. Financial Development, Financing Constraints, and Corporate R\&D Investment [J]. Journal of Financial Research, 2011, 05:171-183.

[12] Zhu Yan, Zhang Mengchang. Empirical Study on Human Capital, R\&D Input and Corporate Performance of Corporate Management Team [J]. Accounting Research, 2013, 11:45-52+96.

[13] Feng Haihong, Qu Wan, Li Minglu. Does Preferential Tax Policy Help Enterprises Increase R\&D Investment?[J]. Studies in Science of Science, 2015, 33(05): 665-673.

[14] Xue Wei, Wei Shijie, Li Feng. Looking at Improvement of China's Additional Deductions Policies for R\&D Expenses from the Perspective of International Experience [J]. International Taxation, 2014, 11:14-18.

[15] Ren Haiyun, Song Weichen. Enterprises' Heterogeneous Factors, Additional Deductions for R\&D Expenses, and $R \& D$ Input [J]. Studies in Science of Science, 2017, 35(08): 1232-1239. 